\title{
The Reporting Verbs and Bias in the Press
}

\author{
Alan Floyd \\ University of La Coruña
}

\begin{abstract}
This article describes one way in which news reports, apparently neutral, subtly show the personal preferences of journalists. It shows the way different people are reported using different reporting verbs, thus prejudicing readers' opinions in favour of or against them. It matters considerably whether the reporting verb is "professed" or "claimed", which have negative connotations, or "explained", "announced" or "pointed out", which have a more positive sound to them. Depending on the context, others, such as "asserted", "stated", "concluded", "argued", "promised and "maintained", are more neutral. In general, those reported favourably respond to a profile of Western, official, elite, establishment speakers.
\end{abstract}

News is much more about what people say than what is done. Most news is in fact reported speech. It is talk about talk, with several stages of reporting often involved. Journalists depend a lot on other sources to report on events, so news is full of second-hand information, announcements, opinions, reactions, appeals, promises and criticisms. One advantage to the journalist of using quotes is that they lend authority to the story (Zelizer, 1989). "Good quotes" mean reporters have been doing their job of news-gathering effectively, as far as newspaper editors are concerned.

Just as, in fictional literature or scientific writings, the narrator gives more space to those who have more importance for his/her theme, so the very fact that a person's words are reported in the press means they are considered important. By relying on quotes from those who are "involved", journalists substitute other people's opinions for the facts of reallife phenomena, because of the aura of authority attached to certain frequently heard voices. High-status sources in government, industry and business are given preference over lower 
status sources, such as the man in the street, in a kind of intelligentsia-based hierarchy. In news discourse, the sources themselves often determine what is a fact, while newswriters "absolve themselves of responsibility" (Tuchman, 1978: 86).

For one's utterances to have news value it is often enough to be an elite person. Roeh (1982: 154) found that out of six hundred stories, sixty-eight per cent featured elite persons saying something, while for a non-elite person the only sure way to get into the news is by being the victim of something, a crime, an accident or a natural disaster. Press briefings, speeches and other staged news events by political and military leaders, interviews supplied by government sources, and reports in studio and on location from consultants and experts outweigh other sources such as interviews of non-elite sources. Powerful politicians need not even speak themselves, as they have bureaucratized or professional organizations who speak and write for them, that formulate their speeches and press releases. So the president, or prime minister, is a primary sources of public understanding of events. Even when (s)he says "No comment" or nothing at all, it is still news (Martín Rojo, 1995: 55). Even when access is fairly provided for alternative voices, however, there is underlying bias against them, one facet of which I propose to study here. Using a corpus of international news in the British newspaper The Times, ${ }^{1}$ I have studied the use of a some selected reporting verbs which, it seems to me, are favourable to the speaker reported.

It is not true that one side is given preferential treatment through being accorded more access through direct speech. I find that both forms are used for both sides, where the reporting clause is followed by the actual words, as in "President Saddam said: 'Right is on our side. Let us fight the infidels and their agents wherever they are.' (January 2nd, by John Holland), and where the reported clause is followed by the reporting clause, as in "... he predicted a military battle throughout the Arab world against the West. "The main thrust of the military battle may be Iraq, but the theatre of our operations includes every struggler and holy fighter ....' he told his army leadership on Sunday" (January 8th, by John Holland). The second passage includes both Saddam's words in indirect speech, and those in direct speech.

Reporting verbs, on the other hand, are significant, even though, like personal pronouns, in spoken English they seldom receive stress in. In newspaper headlines, they are sometimes omitted altogether, as in:

\section{(1) "Washington: "There is no topic for negotiation in the Gulf" (Waugh, 1995: 143).}

The above quotation contains several points of interest. Firstly, "Washington" in this headline has nothing to do with the geographical entity, or with the millions of people living there, but plenty to do with the White House being situated there. Secondly, the headline is a way of compressing or summarizing what the article contains further on. Only the verb "to be" is present. This is typical of the news, where elite people do nothing, action being reserved for the lower orders. Thirdly, it is typical newspaper style of the late twentieth century to talk in monosyllables during short periods of time, with "soundbites" of a few seconds being all the time available, which goes against profound analysis. Fourthly, it is 
seen how Washington talks ex cathedra, as though whether negotiation is proper or not is seen as non-negotiable in itself.

\section{Reporting verbs}

Reporting verbs, when they do appear, whether in direct or indirect speech, are less varied in news discourse than in other kinds of discourse, probably due to the neutrality aimed at by most journalists. There is a complete absence of those reporting verbs that reflect thought processes, such as "He thought / pondered / reflected", as in general the journalist does not know, and probably does not care, what was going through the speaker's mind at the time, unlike a novelist. However, we find plenty of impersonal statements such as "it is thought / believed."

There is a great divide between the two sides in international conflicts, as to which reporting verbs are used, there being certain positive ones which are used practically exclusively to refer to "our" side. I have basically divided the instances into two different teams. On one side are voices which support the Western coalition's war effort in the Gulf crisis, on the other are voices which oppose it.

\section{Favourable Reporting Verbs}

In any narration, there are certain discourse markers that act as a guide as to the reporter's attitude towards the speaker. The following reporting verbs, whether accompanying direct or indirect speech, imply that what the speaker said had at least some truth in it. Some verbs, such as "reiterate" and "repeat" are ostensibly neutral reporting verbs, but nevertheless have positive connotations. Others, like "say" and "tell", are really neutral and need the accompaniment of other devices, usually an adverb such as "solemnly", to make them less impartial.

(2) The \$7billion relief announced for Egypt by the Bush administration... (September 11th, 1990, by Philip Webster).

Apart from the positive label "administration", which implies the democratic nature of the government, unlike "regime", for example, which is reserved for undemocratic countries, the relief is talked of as though it were already half-way there. The reporting verb "announce" is sometimes neutral, but in some cases, such as the above, it is more biased than the more neutral "promise." An "announcement" when it comes from official sources, which the word usually implies, tends to be seen as true. 
There is an emotional charge to the verb "appeal", which is often used for a cry from the heart for right-sounding things such as peace, comprehension and help. It has generally favourable connotations:

(3) The Pentagon is disclosing few details of military movements and has appealed to the media to withhold information of use to Iraq (August 10th, by Martin Fletcher).

"Appeal" appears frequently in the news both as a noun and a verb. It is used greatly by the Pope, the Secretary General of the United Nations, and the peace movement. The use of "appeal" in this case is somewhat ironic, as it means the Pentagon is unable to enforce its will on the media, but in 1991 there were witnessed a unprecedented amount of wartime censorship and press pooling, which were far more than "appeals."

In the above quotation, we can also the see the reporting verb "disclose." This presupposes the truth of what follows, as by definition one cannot "disclose" what is false but only what is true. This reporting verb presupposes the truth of the statement, and also implies that the reader is being let in to a piece of privileged, confidential information. Almeida (1991: 247) shows how the verb "disclose" presupposes truth, quoting "Administration officials disclosed that...." (From The New York Times 14/12/87). The same is true of "divulge." This is borne out by my study of reporting verbs in the following examples: "President Bush disclosed for the first time yesterday that Iraqi troops were deploying powerful surface-to-surface missiles" (August 9th, by Martin Fletcher) and "Pentagon officials disclosed that some of the 500,000 Iraqi troops had started to change position" (January 29th, by Michael Evans) These presuppose that it is true that the Iraqis were deploying the missiles, and that the US authorities will tell the truth about the Iraqi troops.

Like "disclose", "reveal" is used to describe a speech act that tells the truth, implying privileged information. Although there are some examples of "reveal" where the information comes from Iraq, such as "aerial photographs reveal that the bridge was destroyed", there are no examples of its use by journalists reporting Iraqi spokesmen, politicians or people, or any other Arabs either. Many things are "revealing", many others are "revealed" or "should not be revealed", "can be revealed", and so on, in an impersonal way, and there are numerous "revelations" about the progress of the war, but never with the Iraqi side of the story as the source. The allies "reveal" twenty-four times during this period, while this reporting verb is never used for speech acts from the Iraqi side.

The reporting verb "confirm" is used frequently, and among other features it contains the connotation that the words are only a summary of what was actually said. The expression "The Foreign Office / Whitehall sources / the Pentagon / the White House confirmed" is tantamount to saying that it is true, just as "The Foreign Office Whitehall sources / the Pentagon / the White House refused to / was unable to confirm" implies that the source referred to by the speaker is unreliable, as in: 
(4) The Foreign Office was unable to confirm the ambassador's statement (August 19th, by James Adams).

If some event is "confirmed" or "unconfirmed" it has the suppressed agent "by one of us" behind it. Thus "unconfirmed reports", rather than meaning "unconfirmed by me, the journalist" tends to mean "unconfirmed by the West", as in the following example:

(5) Yesterday's unconfirmed reports that Iraqi aircraft were seen loading poison-gas weapons. (August 9th, by Michael Evans)

It is very likely that the unnamed source was someone other than Reuters or the Americans, and so is considered "unconfirmed", a word that would not have been used had the source been British or American officialdom. The journalist is thus giving more credence to some sources than others. The original words are hidden, but the use of "confirmed" rather than "backed" or "supported", for instance, indicates the reliability of those confirming. As is seen in the following quotations, it is not enough that the French say something. For British reporters, it must be "confirmed" by the British or Americans to become believable:

(6) Defence secretary, Richard Cheney, confirmed in Warsaw that 150,000 American reinforcements.... (December 5th, 1990, by Michael Evans).

(7) Pierre Joxe... claimed that thousands of Iraq's Republican Guard had been killed. These figures were not, however, confirmed by the British or American spokesmen (February 8th, 1991, by Michael Evans).

"Explain" is a positive reporting verb. One usually only "explains" what is true. There is a great difference between "The Prime Minister explained that the Budget measures were necessary" and "The Leader of the Opposition claimed that the budget measures were unnecessary" (Ghadessy, 1988: 8), for the former implies truth while the latter does not.

(8) When the shooting starts it will be important to explain to world opinion why war against Saddam is necessary (August 19th, 1990, Leading article).

(9) Mr Bush had to explain to Congress why the liberation of Kuwait was essential to the national interest (November 14th, 1990, by Martin Fletcher).

The examples above merge in the journalists ideas with those of the Western leaders, presupposing that war against Saddam was indeed necessary and that the liberation of Kuwait indeed essential, otherwise the journalist could have written "why he thought the liberation of Kuwait was essential...." and "why the allies think war against Saddam is essential." This reporting verb is more neutral than "disclose" but even when it refers to the 
Iraqi side, it is hedged about modally with phrases such as "tried to explain", "need to explain" or "said he would explain." The allied leaders' problem, according to The Times, is to explain to the troops why they are there (9), not to "argue", "convince" or "debate", as the position of the government is portrayed as the only reasonable one. One other phenomenon essential to a proper understanding of international news discourse is the frequent use of nominals, where verbs would have conveyed the same meaning. Thus, in the above examples, both "shooting" and "liberation" are nominalizations of their equivalent verbs "shoot" and "liberate", though without the actors being mentioned. Another is found in the following example (10), where "retaliation" does not mention who will do the retaliating.

Only Western sources "inform" or "make clear." The latter reporting verb is often impersonal, with the implied subject being the West, as in:

(10) It should be made clear that any further Iraqi incursions into Kuwait would be met with massive retaliation (February 3rd, 1991, by Robert Harris).

If one "points something out", "emphasizes the point", "underlines the point", "rams the point home" or "makes the point that....", all found in the texts selected, it is to be assumed by the reader that the "point" is partly valid at least. So when British sources said that Baghdad's action "underlined the importance of the points she (Mrs Thatcher) was going to make" (August 3rd, by Peter Stothard), they are taking for granted that the point made is true. Or if it is said that "Saddam needs to get the point", or ."... the (Baker) tour is designed.... to ram the point home to President Saddam Hussein that the US is deadly serious" (November 5th, by Martin Fletcher), it is presupposed that the "point" is worth getting or ramming home. In the same way, it is often said that Western sources "point out" some fact. Sentences such as "As Douglas Hurd, the foreign secretary, has pointed out", "Whitehall sources pointed out", "The Pentagon discreetly pointed out", "Pentagon sources pointed out", "State Department officials pointed out" and so on, are quite frequent.

The reporting verb "spell out" is as authoritative as "point out", but far less frequent. "John Major spelt out yesterday that only one man could now prevent war." (December 22nd, by Robin Oakley), and "Then Tom King, the defence secretary, spelt it out on Sunday. "(January 29th, by Michael Evans) Iraq also made certain things very clear at the beginning of the conflict, when it had the whip hand: "Iraq's uncompromising, bullying stance which was spelt out in its government press" (August 2nd, by Michael Theodoulou).

The verb "reiterate" is used exclusively for the allied side. Though it is not obviously biased in favour of the speaker for any semantic reason, the connotations are positive. Perhaps the reason is simply that the allies are the only ones to be frequently given the opportunity to reiterate statements, or perhaps because it is rather more formal and authoritative. "Mr Baker reiterated in a television interview at the weekend...." (December 3rd, by Susan Ellicott) and "Mr Bush reiterated that he would not negotiate over a withdrawal" (December 7th, Anonymous article) are examples. 
"State", which has an authoritative ring to it, is relatively rare, and when it does appear it almost invariably refers to words uttered by an elite person in the West, as in: "Let me state, too, that the United States will not tolerate the use of chemical or biological weapons" (January 13th, transcript of Letter from Mr Bush to Saddam Hussein). However, there is a use of "state" which is more ambiguous, which talks of "stated intentions", "stated determination" or "stated purpose", which implies that the intention or purpose were not the same as those stated: "The French abandoned a previously stated policy of confining operations to Kuwait." (January 25th, by Michael Evans) With this implication it is never applied to the British or Americans.

The implication of "tell of", but not of "tell that", is that the words reported are true, and they are used almost exclusively for utterances of hostages, individual service personnel or escapees from Kuwait or Iraq. "Refugees from Kuwait tell of looting and armed resistance" (August 11th, by Hazhir Teimourian) "British pilgrims tell of their lucky flight from Iraq" (August 17th, by Christopher Walker) Some of these eyewitness reports are unfavourable to Western interests, it has to be said, and one or two come from Iraqis: "A few survivors told of the last minutes before the shelter was hit." (February 14th, by Marie Colvin) It is also used for the words of elite figures, always on the Western side: "Bush tells of "combat terror' as Congress opens war debate" (January 11th, by Martin Fletcher) "Major tells of dangers to come" (January 18th, by Peter Mulligan and Robert Morgan)

The pragmatic force of "tell how" is identical to "tell of" and, unsurprisingly, is never used for the Iraqi side. As in the case of "tell of" it is reserved practically exclusively for refugees' and hostages' reports on the state of occupied Kuwait. In "The woman told how Kuwait was a nation waiting for war" (September 16th, Anonymous article) the implication, if not the meaning of "said that Kuwait was a nation waiting for war" is totally different and would contain less favourable bias towards the woman and consequently against Iraq. As with "tell of" however, a few of the words reported as supposedly true are unfavourable to Western interests: "The report tells how the US, British and French forces, as well as Iraq, have 'filtered and moulded information' to achieve their own objectives." (February 20th, by Melinda Wittstock)

\section{Unfavourable Reporting Verbs}

The Iraqis are afforded less opportunity to speak, but their words are nevertheless reported, subject to some restrictions. They are given less favourable treatment in the matter of reporting verbs.

The reporting verb "allege" sows the seeds of doubt in the reader's mind as to whether the words stated are correct, and consequently the verb, and its related noun "allegation" is applied more to what "they" said:

(11) Iraqi officials alleged that bombs dropped by Tornados on Thursday had missed a bridge and struck an apartment building (February 17th, by Richard Ellis). 
"Allege" is also used to insinuate what is unproved about occupied Kuwait, and journalists occasionally use the word to apply to allied leaders, insinuating that some course of action is viewed negatively.

The clearest example of an unfavourable reporting verb, however, is "claim." A report quoted by Fowler (1991) from The Guardian of 16th April 1986, begins "Libya yesterday claimed to have destroyed an American-manned communication station." Another article, from The Sun, also quoted by Fowler on the same conflict, reads: "Gaddafi's 15-month-old adopted daughter Hanna died in his Tripoli HQ, Libyan doctors claimed. His two youngest sons were also injured." The enemy or outsider "claims" while "we" say, state or explain, make clear, disclose, or "say", as the following example shows:

(12) The ship's Iraqi captain, keen to make the most of the incident, claimed two women had miscarried and two others had had heart attacks when they saw marines boarding the vessel. But a US Navy doctor said nobody was hurt (December 27th, by Michael Theodoulou).

The journalist appears to be giving his own opinion, that is, that the Iraqi captain was trying to "make the most of the incident." The Iraqi is significantly the one who "claimed", while the US doctor "said" that nobody was hurt. In the following example, too, the Iraqi "claim" is countered by "Bush said", juxtaposed with it:

(13) Responding to Iraqi claims that the letter was written in language unsuitable for heads of state, Mr Bush said that it was 'not rude but direct'. He said that.... (January 2nd, by Peter Stothard)

The choice of the verbs "report", "claim" and "said" is a deliberate way of showing who is telling the truth in the following example: "Three American jets and two British Tornados were reported lost yesterday. The spokesman said 15 Iraqi planes had been destroyed and 40 Iraqis killed. The Iraqis claimed, however, that they had shot down 154 allied aircraft." (January 21 st, by Christopher Walker) The implication of some reporting verbs is that the establishment view is better informed, for explanation comes from a position of strength or knowledge, while "claim" may come from a position of weakness, inferiority or ignorance. It is also an indication that speakers have something to prove, to improve their position in public opinion. At the very least it sows the seeds of doubt in the reader's mind.

In the first phase of the crisis even leading articles distanced themselves from the words of the American president. It had yet to be seen how positions would harden. Bush's actual words are placed within inverted commas, as is seen in: "When Bush first sent the troops in early last week, the White House claimed it was sending a small force to defend Saudi Arabia" (August 12th, by John Cassidy). In one article, the reports from each side are listed as: "Allied Claims.... Iraqi Claims.... (January 22nd, War Diary) However, this seeming neutrality is spoilt a little in other similar articles where the two lists are "Claims" and "Iraqi Claims", with "our" being understood in the former case, and when used for Iraqi claims, 
in case there were any doubt, one journalist calls their allegations "spurious claims" (March 3rd, by Marc Weller).

In the following example it is seen how far journalists will go to distance themselves from the Iraqi side:

(14) The Iraqi spokesman repeated previous undertakings not to invade Saudi Arabia, claiming that the "merger" was not a precedent and stating that Baghdad had no ambitions on any other territory (August 9th, by Christopher Walker).

In the course of this brief quotation, we see the use of three different reporting verbs, as if the journalist at each step wants to make it crystal clear that the words are not his own but come from the enemy side. We also see how the inverted commas round the single word "merger" almost certainly distance the journalist from the source.

Certain reporting verbs are only used for "them", for example "taunt", as in "'Kill us or get out' Arabs taunt as rocks and bullets fly in Gaza. (New York Times, 16/12/87) In The Times, this verb is used only once to describe Iraqi words: "Baghdad Radio taunted coalition forces: "Total destruction awaits you'" (February 24th, by Richard Caseby) and on three occasions to describe words used by allied soldiers, though always to deride their companions, not the enemy.

It has to be taken into account, when considering the statistics, that most speakers accessed are Western. Therefore, it is hardly surprising that "explain", for example, occurs less with Iraqi speakers, as they are given less space, less opportunity to "explain" themselves, and this must be taken into account when conclusions are drawn from these statistics. With this proviso, however, it must be said that the overwhelming weight of proof is that favourable reporting verbs are reserved almost entirely for the coalition, while the verbs "allege" and "claim" are reserved for the other side.

\section{Notes}

1. The corpus relates to the newspaper's coverage of the conflict in the Persian Gulf between Iraq and the allied coalition, led by the United States, from August 1st, 1990 to March 15th, 1991.

\section{Works Cited}

Almeida, Eugenie P. (1991): Factuality and Non-Factuality in Newspaper Discourse Unpublished dissertation. Department of Communications, SUNY at Buffalo.

Fowler, Roger (1991): Language in the News. London: Routledge.

Ghadessy, Mohsen (1988): Registers of Written English: Situational factors and linguistic features. London: Pinter Publishers.

Martin Rojo, Luisa (1995): "Division and rejection: from the personification of the Gulf conflict to the demonization of Saddam Hussein." Discourse and Society 6(1): 49-80. 
Roeh, Itzak (1982): The rhetoric of news in the Israel Radio: some implications of style for newstelling, Bohum: Studienverlag Brockmeyer.

Tuchman, Gaye (1978): Making News. New York: The Free Press.

Waugh, Linda R. (1995): "Reported speech in journalistic discourse: the relation of function and text." Text 15(1): 129-173.

Zelizer, Barbie (1989): "Saying' as collective practice: Quoting and differential address in the news." Text 9(4): 369-388. 